\title{
Editorial: Periodontal Disease - A Public Health Problem
}

\author{
Alexandrina L. Dumitrescu* \\ Dental Private Practice, Bucharest, Romania \\ Keywords: periodontitis, gingivitis, inflammation, public health, health literacy, health education
}

\author{
The Editorial on the Research Topic \\ Periodontal Disease - A Public Health Problem
}

In 2010, the World Health Organization published an important report entitled "Equity, Social Determinants and Public Health Programmes" $(1,2)$ revealing that among priority public health conditions, oral health represents a global problem linked to inequalities in social circumstances (3). Periodontal disease, a chronic inflammatory disease resulting in progressive attachment and alveolar bone loss, is, after dental caries, one of the most important oral diseases contributing to the global burden of chronic disease (4), and it meets the criteria for consideration as a public health problem that requires action, as defined by Thomson et al. (5): i) it is widespread as affects "more than $50 \%$ of the adult population, while its severe forms affect $11 \%$ of adults, making severe periodontitis the sixth most prevalent disease of mankind" (6); ii) periodontitis severely impairs the individuals' oral health-related quality of life $(7,8)$, their self-esteem (9) and their general well-being (10). Furthermore, several research studies have associated periodontal disease with various systemic diseases and conditions, such as diabetes, HIV, atherosclerotic vascular disease, rheumatoid arthritis, adverse pregnancy outcomes, obesity, and metabolic syndrome (11-18); iii) the costs of treating the periodontal disease are substantial (19-22); and iv) due to the current state of knowledge of the risk factors implicated in the etiopathogenesis of periodontal disease [e.g., smoking $(23,24)$, alcohol (25-27), poor diet, lack of exercise (28-30), stress, distress, and psychological-coping resistance (31-34)], there is sufficient information to allow the effective control of the common forms of the disease.

Several strategies of controlling periodontal disease have been described, such as the population strategy that requires use of the public health approach for changing health behaviors (e.g., smoking, oral self-care) (35), the secondary prevention strategy, and a high-risk strategy in persons at special risk (5). As non-communicable chronic diseases share numerous risk factors with periodontal diseases (18), The Common Risk Factor Approach (CRFA) and the health promotion approach have been acknowledged as key aspects of the strategies aimed at those who are known to be at high risk $(36,37)$.

Within the dental profession globally, for years, the treatment, control, and prevention of periodontal disease has been under the dominance of the biomedical model emphasized on the molecular and biological basis of disease at the individual level and focused on a professional dependency representation with clinical surgical procedures and on-going maintenance therapy (38). The preventive component in this patient-centered approach was oriented on improving patient oral health and to perform chairside advice and counseling on smoking behaviors $(39,40)$. Several limitations of this traditional clinical approach have been revealed such as (a) the high costs and therefore the limited access for socially disadvantaged, disabled, chronically ill and old populations with high need (41) and (b) it has only immediate short-term positive changes in oral hygiene, bleeding indexes, and knowledge, being ineffective in achieving constant improvements in periodontal outcomes at a population level $(42,43)$.

Received: 12 October 2015 Accepted: 09 December 2015

Published: 08 January 2016

Citation:

Dumitrescu AL (2016) Editorial: Periodontal Disease - A Public Health 
Nowadays, a broader and more comprehensive approach is used in periodontal disease prevention with interventions targeting both local etiologic as well as general risk factors (36). Unfortunately, in both developing and developed countries, the human, financial, and material resources are still in short supply to meet the necessities of oral health care services and to provide universal access, especially in disadvantaged communities (44), the cost of providing dental treatment for periodontitis patients is high and comparable with some non-communicable diseases $(20,45,46)$, while periodontal treatment is scarcely included in oral health-care reimbursement schemes, if available (3). Furthermore, various issues were mentioned when measuring the efficiency of periodontal treatments through several economic evaluation techniques (21).

True population-directed actions for preventing periodontal disease are narrow (3), limited data were published on the contribution of oral health services to the prevention and control of periodontal disease $(11,45)$. Oral health promotion in the form of health education campaigns have been used in the community level using media to obtain sustainable changes in dental health knowledge, attitudes, and behavior $(47,48)$. However, most of the actions concern dental problems other than periodontal health $(3,49,50)$, and only a small number of systematic evaluations of mass education campaigns on periodontal disease have been undertaken (51-56).

Among the strategies that have been described for controlling periodontal disease (5) of special attentions were the population strategy for changing unhealthy lifestyles, particularly those determining tobacco use, alcohol consumption, and oral self-care (plaque removal). The WHO Framework Convention on Tobacco Control (FCTC) was developed as a reaction to the globalization of the tobacco epidemic, smoking being one of the significant risk

\section{REFERENCES}

1. Kwan S, Petersen PE. Oral health: equity and social determinants. In: Blas E, Sivasankara Kurup AS, editors. Equity, Social Determinants and Public Health Programmes. Geneva: World Health Organization (2010). p. 159-76.

2. Petersen PE, Kwan S. Equity, social determinants and public health programmes - the case of oral health. Community Dent Oral Epidemiol (2011) 39:481-7. doi:10.1111/j.1600-0528.2011.00623.x

3. Jürgensen N, Petersen PE, Ogawa H, Matsumoto S. Translating science into action: periodontal health through public health approaches. Periodontol 2000 (2012) 60:173-87. doi:10.1111/j.1600-0757.2012.00451.x

4. Petersen PE, Ogawa $\mathrm{H}$. The global burden of periodontal disease: towards integration with chronic disease prevention and control. Periodontol 2000 (2012) 60:15-39. doi:10.1111/j.1600-0757.2011.00425.x

5. Thomson WM, Sheiham A, Spencer AJ. Sociobehavioral aspects of periodontal disease. Periodontol 2000 (2012) 60:54-63. doi:10.1111/j.1600-0757.2011.00405.x

6. Tonetti MS, Chapple IL, Jepsen S, Sanz M. Primary and secondary prevention of periodontal and peri-implant diseases: introduction to, and objectives of the 11th European workshop on periodontology consensus conference. J Clin Periodontol (2015) 42:S1-4. doi:10.1111/jcpe.12382

7. WHO. Oral Health (2012). Available from: http://www.who.int/mediacentre/ factsheets/fs318/en/

8. Al-Harthi LS, Cullinan MP, Leichter JW, Thomson WM. The impact of periodontitis on oral health-related quality of life: a review of the evidence from observational studies. Aust Dent J (2013) 58:274-7. doi:10.1111/adj.12076

9. Chapple I. Severe Periodontitis Is a Public Health Problem (2014). Available from: http://prevention.efp.org/severe-periodontitis-is-a-public-health-problem/?utm_content=bufferecaf7\&utm_medium=social\&utm_source=facebook.com\&utm_campaign=buffer factors not only for periodontal disease but also for numerous other chronic diseases (3). Regarding the improvement of oral hygiene behaviors, it was suggested that public health interventions should adopt an integrated approach in development of health literacy and appropriate self-care hygiene practices especially in children. Moreover, teaching hygiene skills should be also addressed to caregivers of vulnerable groups in society (e.g., old people, disabled individuals) that may all require special help in maintaining proper oral hygiene $(39,57)$.

An important role in oral health promotion policy development at a local, national, and international level should be played not only by dental public health practitioners, dental professional organizations, and multi-national commercial companies but also by dental research associations who should improve the evidence base for community actions. Moreover, a collaborative approach should be taken with general public health practitioners and other colleagues from the health, educational, and behavioral sciences sector (39).

The present research topic highlighted several of the abovementioned aspects of the epidemiology (Palma and Leite) and assessment of periodontal disease (Ansai et al.), as well as of the risk factors for this condition, such as tobacco use (Kamath et al.). Moreover, mechanisms involved in the impact of periodontitis on systemic health (e.g., complications in pregnancy) were also discussed (Zi et al.).

Overall, all the articles published under the topic "Periodontal disease - a public health problem" contributed to highlight various aspects of the current state of knowledge of the theoretical framework and raised awareness of the periodontal disease problem as a key part of reorienting health services in order to promote periodontal health.

10. Gil-Montoya JA, de Mello AL, Barrios R, Gonzalez-Moles MA, Bravo M. Oral health in the elderly patient and its impact on general well-being: a nonsystematic review. Clin Interv Aging (2015) 10:461-7. doi:10.2147/cia.s54630

11. Petersen PE, Ogawa H. Strengthening the prevention of periodontal disease: the WHO approach. J Periodontol (2005) 76:2187-93. doi:10.1902/ jop.2005.76.12.2187

12. European Federation of Periodontology and the American Academy of Periodontology. EFP Manifesto (2012). Available from: http://www.efp.org/ efp-manifesto/manifesto.html

13. Borgnakke WS. Does treatment of periodontal disease influence systemic disease? Dent Clin North Am (2015) 59:885-917. doi:10.1016/j. cden.2015.06.007

14. Papapanou PN. Systemic effects of periodontitis: lessons learned from research on atherosclerotic vascular disease and adverse pregnancy outcomes. Int Dent $J$ (2015) 65:283-91. doi:10.1111/idj.12185

15. Mealey BL, Oates TW; American Academy of Periodontology. Diabetes mellitus and periodontal diseases. J Periodontol (2006) 77:1289-303. doi:10.1902/ jop.2006.050459

16. Coogan MM, Greenspan J, Challacombe SJ. Oral lesions in infection with human immunodeficiency virus. Bull World Health Organ (2005) 83:700-6. doi:10.1590/S0042-96862005000900016

17. Ryder MI, Nittayananta W, Coogan M, Greenspan D, Greenspan JS. Periodontal disease in HIV/AIDS. Periodontol 2000 (2012) 60:78-97. doi:10.1111/j.1600-0757.2012.00445.x

18. Enwonwu CO, Salako N. The periodontal disease-systemic health-infectious disease axis in developing countries. Periodontol 2000 (2012) 60:64-77. doi:10.1111/j.1600-0757.2012.00447.x

19. Braegger U. Cost-benefit, cost-effectiveness and cost-utility analyses of periodontitis prevention. J Clin Periodontol (2005) 32:301-13. doi:10.1111/j.1600-051X.2005.00802.x 
20. Mohd-Dom T, Ayob R, Mohd-Nur A, Abdul-Manaf MR, Ishak N, Abdul-Muttalib $\mathrm{K}$, et al. Cost analysis of periodontitis management in public sector specialist dental clinics. BMC Oral Health (2014) 14:56. doi:10.1186/1472-6831-14-56

21. Vernazza C, Heasman P, Gaunt F, Pennington M. How to measure the cost-effectiveness of periodontal treatments. Periodontol 2000 (2012) 60:138-46. doi:10.1111/j.1600-0757.2011.00406.x

22. Slots J. Low-cost periodontal therapy. Periodontol 2000 (2012) 60:110-37. doi:10.1111/j.1600-0757.2011.00429.x

23. Fiorini T, Musskopf ML, Oppermann RV, Susin C. Is there a positive effect of smoking cessation on periodontal health? A systematic review. J Periodontol (2014) 85:83-91. doi:10.1902/jop.2013.130047

24. Chambrone L, Preshaw PM, Rosa EF, Heasman PA, Romito GA, Pannuti CM, et al. Effects of smoking cessation on the outcomes of non-surgical periodontal therapy: a systematic review and individual patient data meta-analysis. J Clin Periodontol (2013) 40:607-15. doi:10.1111/jcpe.12106

25. Pitiphat W, Merchant AT, Rimm EB, Joshipura KJ. Alcohol consumption increases periodontitis risk. J Dent Res (2003) 82:509-13. doi:10.1177/154405910308200704

26. Tezal M, Grossi SG, Ho AW, Genco RJ. Alcohol consumption and periodontal disease. The third national health and nutrition examination survey. J Clin Periodontol (2004) 31:484-8. doi:10.1111/j.1600-051x.2004.00503.x

27. Genco RJ, Borgnakke WS. Risk factors for periodontal disease. Periodontol 2000 (2013) 62:59-94. doi:10.1111/j.1600-0757.2012.00457.x

28. Moynihan P, Petersen PE. Diet, nutrition and the prevention of dental diseases. Public Health Nutr (2004) 7:201-26. doi:10.1079/phn2003589

29. Nishida M, Grossi SG, Dunford RG, Ho AW, Trevisan M, Genco RJ. Dietary vitamin Cand the risk for periodontal disease. JPeriodontol (2000) 71:1215-23. doi:10.1902/jop.2000.71.8.1215

30. Al-Zahrani MS, Borawski EA, Bissada NF. Periodontitis and three health-enhancing behaviors: maintaining normal weight, engaging in recommended level of exercise, and consuming a high-quality diet. J Periodontol (2005) 76:1362-6. doi:10.1902/jop.2005.76.8.1362

31. Genco RJ, Ho AW, Grossi SG, Dunford RG, Tedesco LA. Relationship of stress, distress and inadequate coping behaviors to periodontal disease. J Periodontol (1999) 70:711-23. doi:10.1902/jop.1999.70.7.711

32. Peruzzo DC, Benatti BB, Ambrosano GM, Nogueira-Filho GR, Sallum EA, Casati MZ, et al. A systematic review of stress and psychological factors as possible risk factors for periodontal disease. J Periodontol (2007) 78:1491-504. doi:10.1902/jop.2007.060371

33. Warren KR, Postolache TT, Groer ME, Pinjari O, Kelly DL, Reynolds MA. Role of chronic stress and depression in periodontal diseases. Periodontol 2000 (2014) 64:127-38. doi:10.1111/prd.12036

34. Dumitrescu AL. Psychological perspectives on the pathogenesis of periodontal disease. Rom J Intern Med (2006) 44:241-60.

35. Satcher D, Higginbotham EJ. The public health approach to eliminating disparities in health. Am J Public Health (2008) 98:400-3. doi:10.2105/ ajph.2007.123919

36. Sheiham A, Watt RG. The common risk factor approach: a rational basis for promoting oral health. Community Dent Oral Epidemiol (2000) 28:399-406. doi:10.1034/j.1600-0528.2000.028006399.x

37. Ottawa Charter for Health Promotion. International Conference on Health Promotion. Ottawa, ON: Ottawa Charter for Health Promotion (1986).

38. Baehni PC. Translating science into action - prevention of periodontal disease at patient level. Periodontol 2000 (2012) 60:162-72. doi:10.1111/j.1600-0757.2011.00428.x

39. Watt RG, Petersen PE. Periodontal health through public health - the case for oral health promotion. Periodontol 2000 (2012) 60:147-55. doi:10.1111/j.1600-0757.2011.00426.x

40. Baelum V, Lopez R. Periodontal epidemiology: towards social science or molecular biology? Community Dent Oral Epidemiol (2004) 32:239-49. doi:10.1111/j.1600-0528.2004.00159.x
41. Petersen PE, Bourgeois D, Ogawa H, Estupinan-Day S, Ndiaye C. The global burden of oral disease and risks to oral health. Bull World Health Organ (2005) 83:661-9. doi:10.1590/S0042-96862005000900011

42. Watt RG, Marinho VC. Does oral health promotion improve oral hygiene and gingival health? Periodontol 2000 (2005) 37:35-47. doi:10.1111/j.1600-0757.2004.03796.x

43. Kay L, Locker D. Is dental health education effective? A systematic review of current evidence. Community Dent Oral Epidemiol (1996) 24:231-5. doi:10.1 111/j.1600-0528.1996.tb00850.x

44. Kandelman D, Arpin S, Baez RJ, Baehni PC, Petersen PE. Oral health care systems in developing and developed countries. Periodontol 2000 (2012) 60:98-109. doi:10.1111/j.1600-0757.2011.00427.x

45. Fardal $\varnothing$, O’Neill C, Gjermo P, Fardal E, Sandvik L, Hansen BF, et al. The lifetime direct cost of periodontal treatment: a case study from a Norwegian specialist practice. J Periodontol (2012) 83:1455-62. doi:10.1902/jop.2012.110689

46. Pennington M, Heasman P, Gaunt F, Güntsch A, Ivanovski S, Imazato S, et al. The cost-effectiveness of supportive periodontal care: a global perspective. $J$ Clin Periodontol (2011) 38:553-61. doi:10.1111/j.1600-051X.2011.01722.x

47. Saito H, Kawaguchi Y. Halitosis prevention campaign: a report of oral health promotion activities in Japan. Int Dent J (2002) 52:197-200. doi:10.1002/ j.1875-595X.2002.tb00924.x

48. Schou L. Use of mass-media and active involvement in a national dental health campaign in Scotland. Community Dent Oral Epidemiol (1987) 15:14-8. doi:1 0.1111/j.1600-0528.1987.tb00473.x

49. Rogers JG. Evidence-Based Oral Health Promotion Resource. Melbourne, VIC: Prevention and Population Health Branch, Government of Victoria, Department of Health (2011).

50. Wright FAC, Satur J, Morgan MV.Evidence-Based Health Promotion-Resources for Planning. No. 1-Oral Health. Melbourne, VIC: Dental Health Services, Victorian Government Department of Human Services (2000).

51. Bakdash MB, Lange AL, McMillan DG. The effect of a televised periodontal campaign on public periodontal awareness. J Periodontol (1983) 54:666-70. doi:10.1902/jop.1983.54.11.666

52. Horowitz AM. The public's oral health: the gaps between what we know and what we practice. Adv Dent Res (1995) 9:91-5. doi:10.1177/0895937495009 0022201

53. Mårtensson C, Söderfeldt B, Halling A, Renvert S. Knowledge on periodontal disease before and after a mass media campaign. Swed Dent J (2004) 28:165-71.

54. Sögaard AJ. The effect of a mass-media dental health education campaign. Health Educ Res (1988) 3:243-55. doi:10.1093/her/3.3.243

55. Mårtensson C, Söderfeldt B, Andersson P, Halling A, Renvert S. Factors behind change in knowledge after a mass media campaign targeting periodontitis. Int J Dent Hyg (2006) 4:8-14. doi:10.1111/j.1601-5037.2006.00158.x

56. Gholami M, Pakdaman A, Montazeri A, Jafari A, Virtanen JI. Assessment of periodontal knowledge following a mass media oral health promotion campaign: a population-based study. BMC Oral Health (2014) 14:31. doi:10.1186/1472-6831-14-31

57. Zusman SP, Eaton KA, Harris M, Amariei C. A pilot project to improve the oral health of orphans and of the elderly in residential care in Constanta, Romania. Community Dent Health (2015) 32:89-92. doi:10.1922/ CDH_3435Zusman04

Conflict of Interest Statement: The author declares that the research was conducted in the absence of any commercial or financial relationships that could be construed as a potential conflict of interest.

Copyright (C) 2016 Dumitrescu. This is an open-access article distributed under the terms of the Creative Commons Attribution License (CC BY). The use, distribution or reproduction in other forums is permitted, provided the original author(s) or licensor are credited and that the original publication in this journal is cited, in accordance with accepted academic practice. No use, distribution or reproduction is permitted which does not comply with these terms. 